\title{
Gradhiva
}

GRADHI

Revue d'anthropologie et d'histoire des arts

$1 \mid 2005$

Haïti et l'anthropologie

\section{Anténor Firmin and Haiti's contribution to anthropology}

Anténor Firmin et sa contribution à l'anthropologie haïtienne

\section{Carolyn Fluehr-Lobban}

\section{(2) OpenEdition}

\section{Journals}

\section{Electronic version}

URL: http://journals.openedition.org/gradhiva/302

DOI: $10.4000 /$ gradhiva.302

ISSN: $1760-849 X$

\section{Publisher}

Musée du quai Branly Jacques Chirac

\section{Printed version}

Date of publication: 1 May 2005

Number of pages: $95-108$

ISBN: 2-915133-08-5

ISSN: 0764-8928

\section{Electronic reference}

Carolyn Fluehr-Lobban, « Anténor Firmin and Haiti's contribution to anthropology », Gradhiva [Online],

1 | 2005, Online since 10 December 2008, connection on 01 May 2019. URL : http://

journals.openedition.org/gradhiva/302; DOI : 10.4000/gradhiva.302

This text was automatically generated on 1 May 2019.

(c) musée du quai Branly 


\title{
Anténor Firmin and Haiti's contribution to anthropology
}

Anténor Firmin et sa contribution à l'anthropologie haïtienne

\author{
Carolyn Fluehr-Lobban
}

1 Anténor Firmin's major work, De l'égalité des races humaines (Anthropologie positive) was published in Paris in 1885 and while a foundational text in anthropology was largely ignored or dismissed (FluehrLobban 2000). Recovered only recently, the manuscript was translated and introduced into English by Asselin Charles as The Equality of the Human Races (Positivist Anthropology) (2000), one hundred and fifteen years after its original publication ${ }^{1}$. From 1884 to 1888 , during his years in France as a Haitian emissary, Firmin was one of the three Haitian members of the Paris Anthropology Society ${ }^{2}$, whose name remained on the roster until after his death in $1911^{3}$. Although a member of the Société who attended many of its meetings, his voice was effectively silenced by racialist physical anthropology dominant at the

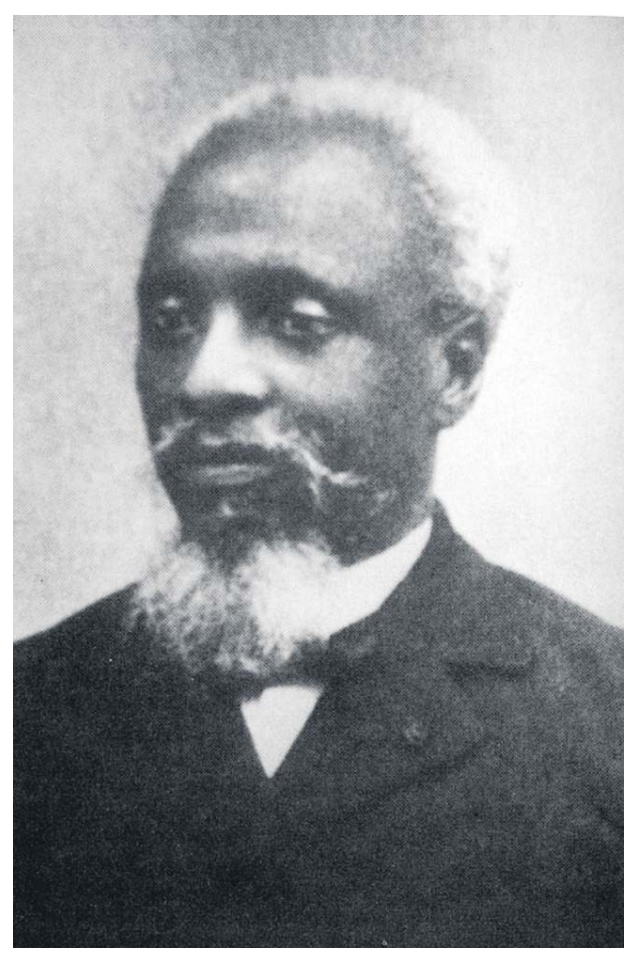
time, and by his race. In the Mémoires that provide a transcript of the Sociétés deliberations are recorded the two occurrences in which Firmin rose to speak. At one point he stood his ground to challenge the biological determination of race that pervaded the prevailing physical anthropology of Broca and others when he was confronted by Clémence Royer (a pioneering woman of science who translated Darwin's Origin of Species into French) who asked Firmin if his intellectual 
ability and presence in the Société were not the result of some white ancestry he might possess. Firmin tells us in his own words in the Preface to The Equality of the Human Races that he wanted to debate with those who «divide the human species into superior and inferior races» but he feared his request would be rejected. «Common sense told me that I was right to hesitate. It was then that I conceived the idea of writing this book» (Firmin 2000: LIV). We now know that a signed copy conveying «Hommage respectueux à la Société d'anthropologie de Paris, A. Firmin» was presented to the Paris Anthropological Society in 1885 , and that no review or further mention of the book, beyond it having been received, was made in the Mémoires d'anthropologie, the periodical of the Society.

Paul Broca (1824-1880) founder of the École d'anthropologie de Paris

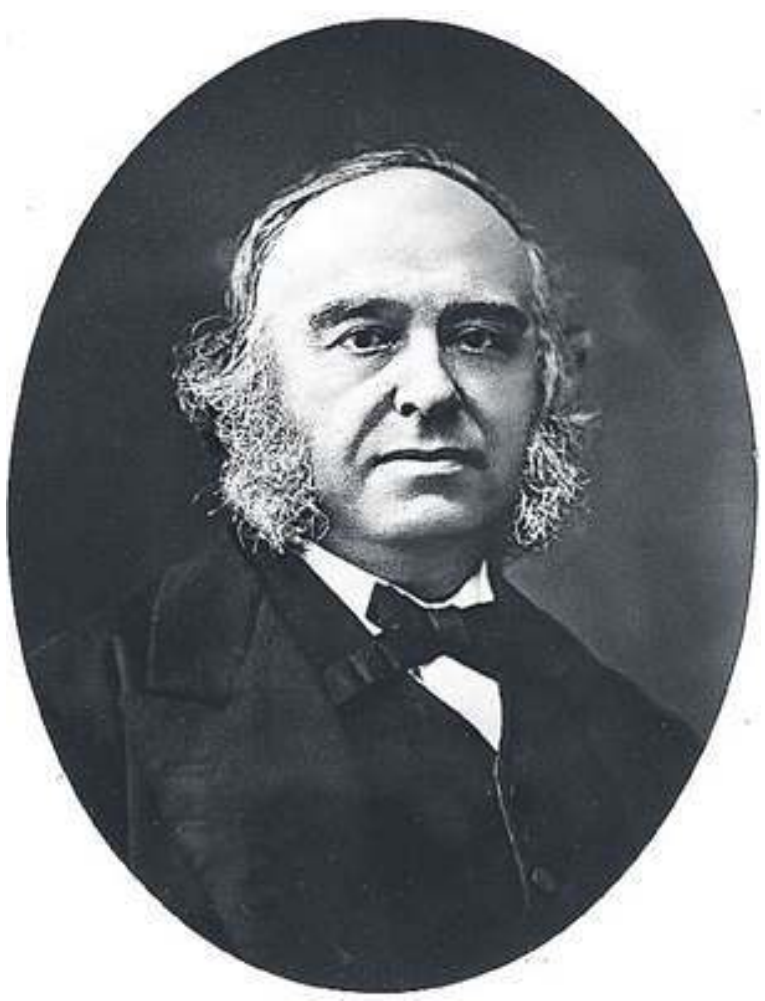

(c) musée du quai Branly, photo J. Oster

2 The publication date of 1885 of De l'égalité des races humaines... marks it as a pioneering text in anthropology because the date falls well within the time framework of the other foundational texts in the field such as Lewis H. Morgan's Ancient Society (1877) and Edward B. Tylor's Anthropology (1881). Although Franz Boas began his «geographical» writings about Cumberland Sound and Baffin-land in 1884-1885, he did not produce a synthetic work of anthropology until The Mind of Primitive Man, in 1911 - that being the year of Firmin's death. Paul Topinard, one of the French racialist physical anthropologists to whom Firmin devotes a great deal of his criticism, published Éléments d'anthropologie générale, in 1885, the same year as De l'égalité des races humaines. In this work, Topinard outlines the general principles of French physical anthropology - racialist, polygenist, and grounded in biologically fixed notions of race «proved» by the science of anthropometry - brought to technical perfection by the French physiciansanthropologists. Firmin constructed a positivist argument, critical of French racialist anthropology that was dramatic and significant. 


\section{Firmin, anthropologist and positivist}

In more than 400 pages, The Equality of the Human Races (Positivist Anthropology) embraces topics in what was to become the four-field study of humanity, including physical anthropology, archaeology, linguistics and ethnology. It is clear from the first chapter, devoted to «Anthropology as a Discipline», that Firmin's vision is one of a comprehensive study of humanity, with such potential breadth that all other sciences become as «tributaries to it» (Firmin 2000: 3). Firmin reviewed and assessed the philosophical and scientific tradition that had shaped the nascent science of anthropology from Immanuel Kant to Herbert Spencer. He defined anthropology as «the study of Man in his physical, intellectual, and moral dimensions as he is found in any of the different races which constitute the human species» (ibid.: 10). A broad integrated science of anthropology was envisioned in which he distinguished between ethnography - the description of peoples -, and ethnology - the systematic study of these same peoples from the perspective of race. The anthropologist comes in once the ethnographer and ethnologist have completed their work. Anthropology is comparative, separating man from the other animals, addressing the questions: «What is the true nature of man? To what extent and under what conditions does he develop his potential? Are all human races capable of rising to the same intellectual and moral level?» Anthropology requires the effort of the best minds? «It goes without saying that if they are to come up with valid results, anthropologists must do more than establishing some arbitrary ranking of the human races and their respective aptitudes» (Firmin 2000: 12-13). Anthropology has been the discipline which can best provide answers to the great problem of the origin and nature of man and the question of his place in nature (ibid.: 2).

Racial Anatomy

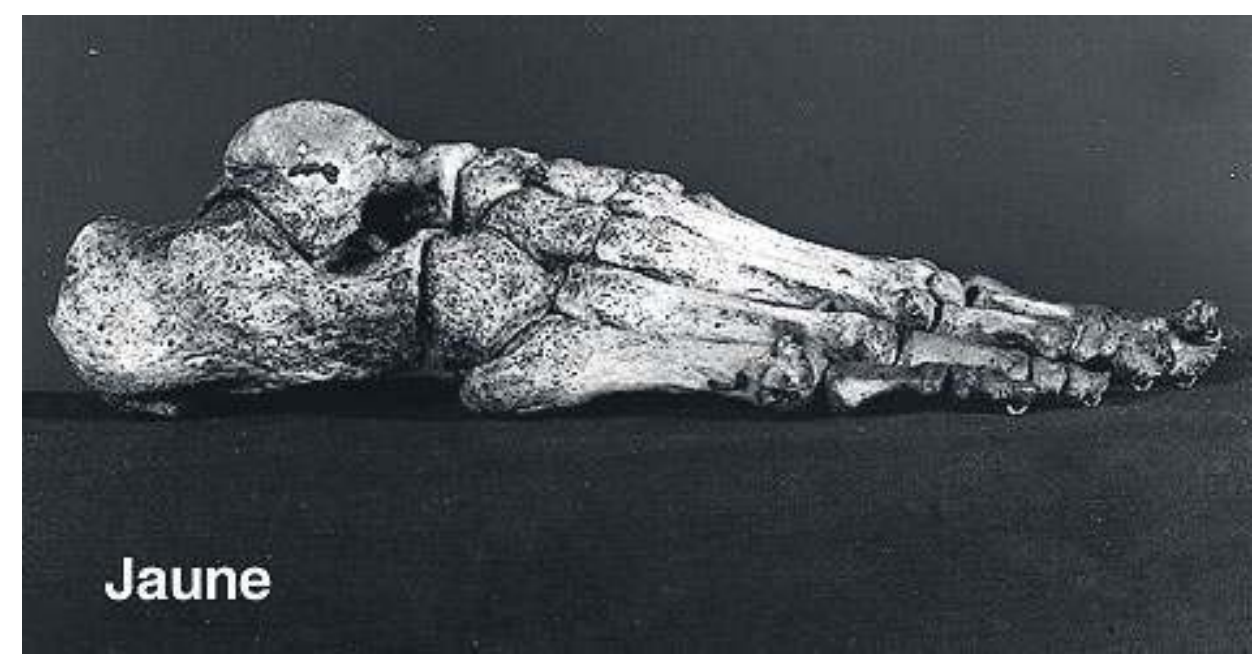



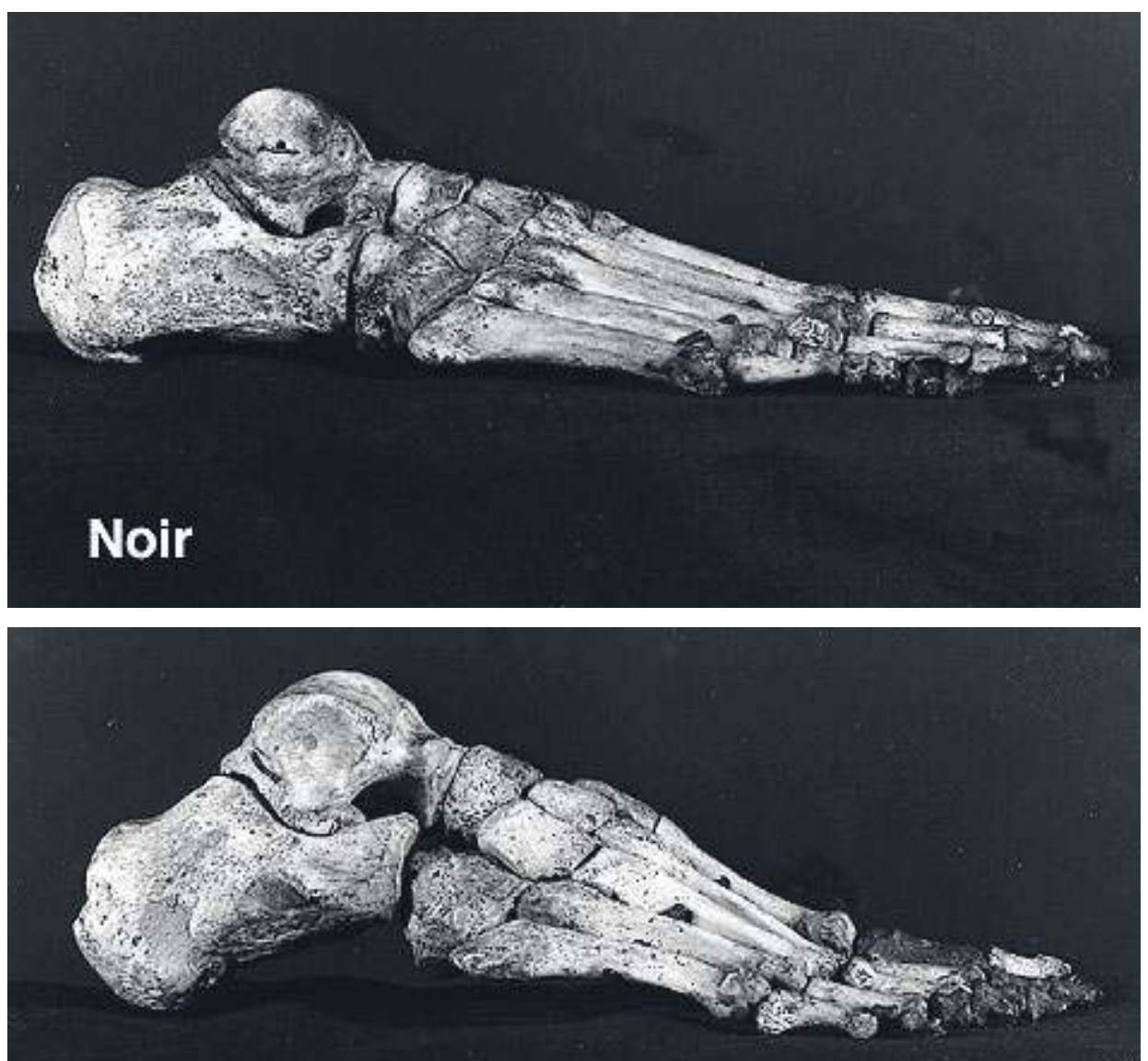

\section{Blanc}

(c) musée du quai Branly

4 Although Marvin Harris (1968: 464) credits Émile Durkheim with founding a school of anthropology that led French racialist and biologically reductionist social science to a modern «sociology» of man, it may well be that the credit belongs, in part, to Anténor Firmin. Firmin grounded his scientific study of humanity and his anti-biological argument for the equality of humans in Comtean positivism. His book is subtitled Positivist Anthropology, because he argues, using August Comte's ideas, that the case for racial equality is to be made using scientific facts, not a priori assumptions about racial difference or philosophical assertions of racial difference.

5 August Comte is identified as a founder or the founder of sociology whose writings in the 1830s and 1840s inspired a number of social scientists, including anthropologists (besides Firmin) from John Stewart Mill to Lévy-Bruhl, Marcel Mauss, and Émile Durkheim. He asserted that mankind is part of the natural world and must be studied as such, a perspective that nearly all social scientists in the 19th century shared (Adams 1998: 171). Comte's use of «fact», «theory», «law» - a clear empiricism - is probably what most attracted Firmin. «Facts» corresponded to what we call «data» today, however «theory» for Comte encompassed models, classifications, generalizations - any framework into which facts might be fitted. He stressed that the comparative method must be applied to a worldwide ethnographic data-base (ibid.: 45). «Positivism», thus understood, is more a methodology than a philosophy, but Comte succeeded in giving this methodology to social science, establishing it as a part of natural science that broke away from the 
tradition which previously had been associated with moral philosophy (ibid.: 341-342). It was this empirical methodology and the placing of anthropology as a new social science in the natural sciences that was useful for Firmin.

Durkheim's study of man was to become associated more with sociology because of the conservative French science education that continued to view «anthropology» only as physical anthropology, relegating it to a narrow, biological treatment of humans. Although Durkheim wrote a great deal about ethnography, and his landmark publications, such as The Rules of the Sociological Method, The Division of Labor in Society, The Elementary Forms of the Religious Life, contributed to anthropological theory and formed the basis for social anthropology and British structural-functionalism, positivism was more influential for sociology than for anthropology. Tallcott Parsons (1949: 307) wrote that: «Durkheim is the spiritual heir of Comte, and all of the principal elements of his earlier thought are to be found foreshadowed in Comte's writings.»

7 Firmin places Comte in a line of great scientific codifiers from Aristotle to Bacon, Bentham, Ampère, and Herbert Spencer. He traces anthropological interest among philosophers from Kant to Hegel, Buffon and Cuvier, Linnaeus to the French Geoffroy Saint-Hilaire and Bory de Saint-Vincent. Following Comte and the positivist school, Firmin (2000: 11) encouraged the thorough study of humanity from the cosmological, biological, sociological, and philosophical perspectives. Throughout his book, Firmin practices positivist science, examining tables of comparative craniometric data, noting their irregularities and the means by which Broca and Morton, and other racialist scientists manipulated the numbers: by cubing skull measurements, these physical anthropologists were able to draw their intended conclusions. After analyzing various scholars' data on the cephalic index, measuring degrees of superior dolichocephaly and inferior brachycephaly, he concludes that this index provides anthropologists with insufficient ground for dividing the races into distinct groups (ibid.: 100). Broca's facial index, whereby the most primitive black race may be close numerically to the Parisian, is also subjected to a critical scrutiny! He subjects the nasal index, the vertical index, the orbital index to a similar scrutiny noting that a rational classification is impossible when the data used to generate them are «not only erroneous and irregular, but also often contradictory» (ibid.: 109). The confusing and often conflicting craniological charts are entertaining to Firmin, who would normally dismiss them were they not taken so seriously by the anthropologists. And forecasting a different composition of the scientific community in the 20th century he comments:

"Can anthropologists continue to record these figures without modifying those so assertive theories they have erected? Their science will face certain discredit when, in the twentieth century, it is subjected to the critique of Black and White, Yellow and Brown scientists who can write as well and handle as expertly the instruments manufactured by the Mathieu Company [producers of anthropometric instruments], instruments that bring such eloquent results, even in the hands of scientists who doubt their effectiveness» (ibid.: 102)

«Motivated by an insatiable thirst for truth and the obligation to contribute, no matter how modestly, to the scientific rehabilitation of the Black race whose pure and invigorating blood flows in my veins, I take immense pleasure in navigating through these columns of figures arranged with such neatness for the edification of the intellect» (ibid.).

So, Firmin pursued the study of all of those «anthropological doctrines which have assumed the mantle of the august name of science while actually usurping its place» (ibid. : 108). For him, not only do craniological measures fail the test of positivist science, but all 
other racialized anthropometric devices and classifications - such as those dealing with hair and skin pigmentation - are also treated as arbitrary and subjective (e.g. the arbitrariness of making a distinction between inferior wooly hair and superior straight hair) and ultimately as non-scientific. Firmin is among the first to locate skin color with the substance melanin, constituted of «fine granules under the epidermis» giving the Ethiopian's skin its black hue (ibid:: 118).

Handsome Male Caucasian Type (Lord Byron)

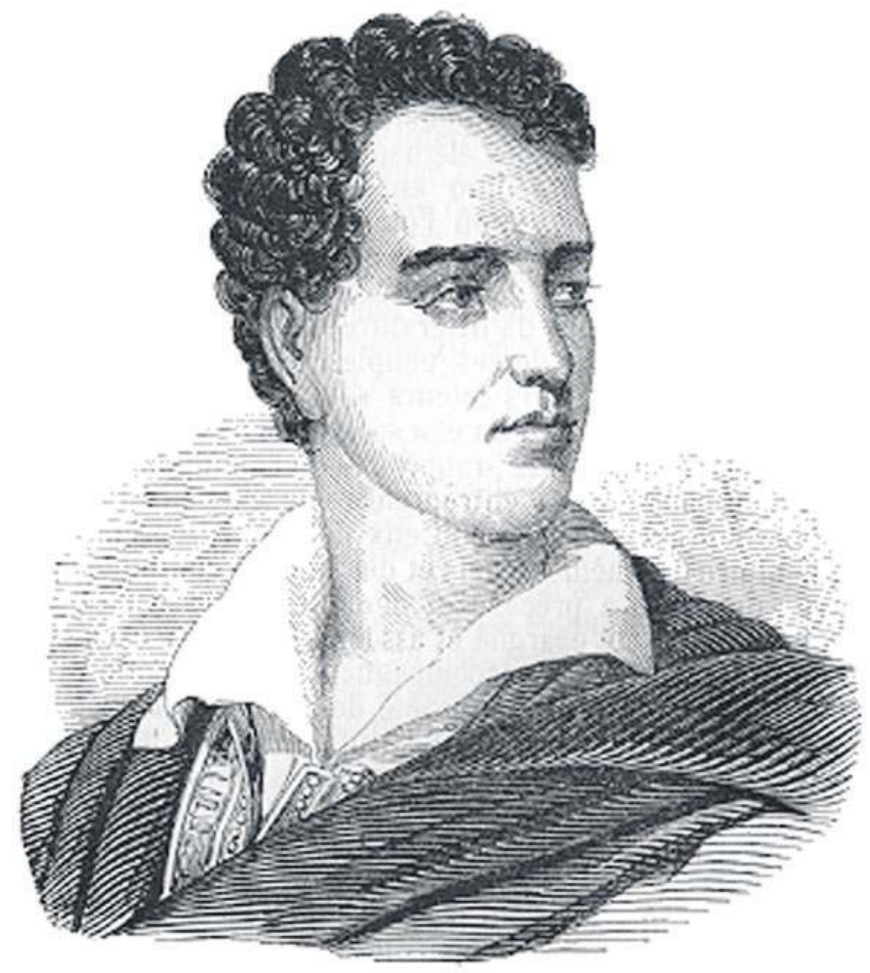

droits réservés

9 All of this «science» amounts to the "Artificial Ranking of the Human Races», the title of Chapter six of Firmin's book. Indeed, Firmin devotes almost half of his work to a critical analysis of racialist anthropometry and racist classifications, lending support to the doctrine of the inequality of human races. Rather than using the terms «racist» and «racialist» that I have employed, Firmin's text notes the «bizarre», the «curious», the «illogical» notion of the inequality of the races.

The Comtean-Durkheimian tradition did diverge from the path of American anthropological historical particularism led by Franz Boas. Both French and American mainstream traditions diverged from Marx, Morgan, and Spencerian dialectics and evolutionism. For Comte, positivism was supposed to steer a course between the materialism of Hegel, Marx and the idea of revolution, and the idealism of the counterrevolution more associated with the French (Harris 1968: 473).

11 Nearly four decades before Franz Boas makes a similar observation in Race, Language and Culture (1940), Firmin devoted considerable effort in separating language from race, noting that it is an unreliable basis for the classification of race (Firmin 2000: 120-135). 


\section{Inspiration to caribbean scholars}

12 Anténor Firmin is a forgotten founder of anthropology whose contribution to French anthropology could have been fruitful, but was ignored. It appears that the members of the Paris Anthropological Society never opened De l'égalité des races humaines, and were not able to receive its message. Firmin's tome was lost to francophone anthropology and only remembered in Haiti and among Pan-Africanist and vindicationist scholars of color. His signal and pioneering contributions to an empirical and critical anthropology, especially as regards race, were lost to the mainstream development of that discipline in Europe and North America, in the formative years of the 19th century, and thus to the decades of consolidation and growth of anthropology in the 20th century.

However, Firmin was never forgotten in Haiti, either as a politician and diplomat, or as a scholar. Anténor Firmin and other 19th century scholars, such as Louis-Joseph Janvier and Hannibal Price, are still remembered and revered in Haiti today. And his example was inspirational to Jean Price-Mars, the founder of ethnology and folklore studies in Haiti. According to Magdaline Shannon (1996: 163), Price-Mars «had early in life developed goals based upon the ideas of such leaders as Anténor Firmin and Hannibal Price» ${ }^{4}$. Some of Price-Mars earliest public lectures focused on the equality of human races, sounding so much like Firmin that President Nord Alexis accused Price-Mars of being a «Firminist» and that his talk was «seditious» (ibid.: 21). This was around 1906 while Firmin was still actively opposing the Alexis government from his exile in St Thomas.

The influence of Firmin on Price-Mars is acknowledged in many of his writings and especially in the latter's last work, Anténor Firmin (1978). Both were scholar-politicians in the Haitian way of not dividing the world of ideas from the world of politics. They were separated by one generation. Firmin was born in 1850 and was 61 when he died in 1911, while Price-Mars was born in 1875 and died at the age of 91 in 1964. Price-Mars taught at the Lycée Petion where Firmin was a student. Since both were intellectuals and politicians, they were appointed Ministers to Paris - Firmin in 1884, Price-Mars in 1915 as is usual for removing troublesome individuals. Being scholars both were committed to proving that races were equal, Firmin challenging racist French physical anthropology, which he encountered during his years in Paris, and was symbolized in Paul Broca, and Price-Mars responding to Gustave Le Bon, who formulated a collective and racist social psychology emphasizing the inferiority of the black man. Price-Mars read Le Bon while he was a medical student in Paris. He later met and challenged him. Le Bon replied asking him why, if he believed so strongly in the equality of races, he did not write about his country (Shannon 1996: 233). While travelling as a physician around the countryside, Price-Mars got interested in studying the Haitian peasantry and could thus observe Vodou, which impressed him for its religious syncretism between African animism and French Catholicism and, moreover, whose ethnological study he validated, a subject that Firmin did not address.

\section{Négritude and pan-africanism}

15 Firmin has been recognized as an early Pan-Africanist more than he has as an anthropologist. G. R. Couthard (1962: 117) notes that: «Writers like Anténor Firmin, Hannibal Price, Claude McKay, George Padmore, and Jean Price-Mars were in the 
vanguard of the revaluation of African culture long before the nationalist awakening in Africa and before the concept of "négritude" was developed in the Caribbean.»

Although Jean Price-Mars is usually credited with being the founder of «indigénisme» and later Léopold Senghor hailed him as the «Father of Négritude» (Fouchard 1990: v), it is probable that Firmin and other illustrious minds of Haiti's 19th century intellectual elite laid the primary foundation for what was to become the «négritude movement». At least four chapters (out of twenty) in The Equality of the Human Races speak directly to the primary role played by the Black Race in world history and civilization ${ }^{5}$. A cursory reading of not only these chapters but of the entire volume reveals Firmin to be an early proponent of négritude without arrogance or apology. Beyond his ideas clearly enunciated in 1885, Firmin attended the First Pan-African Congress in London in 1900, which was also attended by W.E.B. DuBois. Had he not been preoccupied with Haitian politics and a bid to become President as head of a Firminist movement, ending in his exile in St Thomas ordered by President Nord Alexis, Firmin might have continued to be involved on an international level with the nascent Pan-Africanist movement. At a speech at the University of Ghana in September 1964, Kwame Nkrumah acknowledged Firmin as a New World pioneer of Pan-Africanism:

«And let us not forget the important contributions of others in the New World, for example, the sons of Africa in Haiti such as Anténor Firmin and Dr Jean Price-Mars, and others in the United States such as Alexander Crummell, Carter G. Woodson, and our own Dr DuBois.» ${ }^{6}$

Lyle Shannon, the husband of Magdaline Shannon, the translator of Jean Price-Mars' classic work Ainsi parla l'oncle, wrote to me upon learning of the translation of De l'égalité des races humaines:

«Firmin was one of Haiti's most distinguished patriots. His ideas led to the concept of "Négritude". Although people did not at the time think of it that way and despite the appreciation of Jean Price-Mars who predicated his own work on that of Firmin, he remained relatively obscure except in Haiti.» ${ }^{7}$

18 Many white and black intellectuals see Price-Mars as the greatest of Haitian intellectuals, and consider and call him «Father of Négritude.» He never acknowledged this claim although he lived well into the 20th century and witnessed both the end of European colonialism in Africa and the postcolonial rise of ideological and political négritude. Others can claim this title; in 1934, Aimé Césaire of Martinique, French Guyanese Léon Damas and Senegalese Léopold Senghor launched «L'Étudiant noir», a movement of universal consciousness that Césaire called «négritude». Despite this self-assessment, Price-Mars was unanimously chosen as President of the First Congress of Black Writers and Artists, held in Paris in 1956, and at 90, Presidents Ahmed Touré of Guinea and Léopold Senghor at Conakry proclaimed him «the incomparable Master». It may have been from Price-Mars that Kwame Nkrumah learned of Anténor Firmin.

19 Although Price-Mars grounded the study of Haitian ethnology, religion and folklore within the African continent, he nonetheless envisioned Haitians as being part of humanity without the need of «noirism». This view parallels that of Firmin whose positivist assertion that the races are biologically equal was matched by a moral imperative that in mind and spirit as well humanity is unitary, drawing upon a common heritage. He writes in his Conclusion to The Equality of the Human Races (2000: 450):

«Returning to the truth they will realize that human beings everywhere are endowed with the same qualities and defects without distinction based on color or anatomical shape. The races are equal; they are all capable of rising to the most 
noble virtues, of reaching the highest intellectual development; they are equally capable of falling into a state of total degeneration. Throughout all of the struggles that have afflicted, and still afflict, the existence of the entire species one mysterious fact signals itself to our attention. It is the fact that an invisible chain links all of the members of humanity in a common circle. It seems that in order to prosper and grow human beings must take an interest in one another's progress and happiness, and cultivate those altruistic sentiments which are the greatest achievement of the human heart and mind.» thought, Firmin in the late 19th century and Price-Mars for well over half of the 20th. With Firmin as his intellectual antecedent, Price-Mars acknowledges his pioneer work and contribution to anthropology, and bows deeply to Firmin as scholar, diplomat, patriot and politician. No where is this more obvious than in the biography that PriceMars pens as his last work, Joseph Anténor Firmin, which was published posthumously in 1978. In this work, Price-Mars surveys and comments upon Firmin's political and diplomatic career in Haiti, in France, and his successful staving off of the cession of the Môle of St. Nicolas by the United States while Frede-rick Douglass was the American Consul General to Haiti ${ }^{8}$.

21 He also devotes a chapter to Firmin as an homme de sciences in which he extols the importance and value of the contributions made with De L'égalité des races humaines. Referring to Firmin as a prodigy, he marvels at the remarkable achievement of writing a book of such a scope in only eighteen months, during his first stay in Paris, between 1883 and 1888, noting that this is the sort of work that would take others years of research and reflection to accomplish. Yet, knowing anthropology to be a false science, he nonetheless embraced the potential of it and this is how he came «to his vocation as an anthropologist» (Price-Mars 1978: 148). Price-Mars remarks especially on Firmin's critique of anthropometry and craniometry, noting that, had the world heeded his ideas, the tragedy of «Hitlerism» or Nazism might have been avoided. He points to Firmin's recognition of Egypt as an African civilization, including Nubia and often referencing Meroë (Ethiopia) in his praise of ancient Africa. His arguments would have provoked a «scandal» in Europe, so much did they represent a break with the prevalent ideas of his time. He suggests a close linkage with the ideas of Cheikh Anta Diop in Nations négres et culture and acknowledges the work of Basil Davidson Africa Before the Europeans, both popular in the 1960s when his homage to Firmin was published. Recognizing the «pioneering» role played by both De L'égalité des races humaines and Firmin himself among Haitian scholars, Price-Mars also mentions others in this constellation of scholarly greats, including Beauvais Lespinasse, Histoire des affranchis de Saint-Domingue, and Hannibal Price who wrote De la réhabilitation de la race noire par la République d'Haïti (1900), from whom Price-Mars had taken his name.

\section{On race}

Comparing the thought of Firmin and Price-Mars, they can be considered to be parallel and complementary. Both men were dedicated equalitarians on the matter of race; and both were committed «vindicationists» and «rehabilitationists», recognizing that the ideology of the inferiority of the black race has scarcely changed between the 19th and 20th centuries, or for that matter from its origins in the dark age of the 18th century, «Enlightenment».

Gradhiva, 1 | 2005 


\section{RACES HUMAINES}

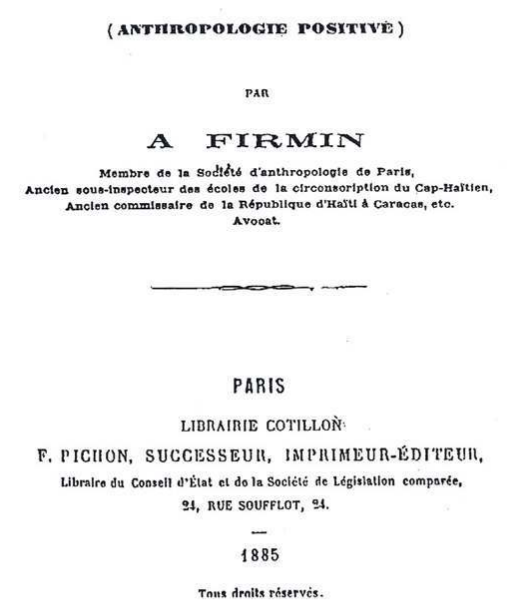

droits réservés

Price-Mars regarded the race concept as a myth, like his intellectual predecessors Firmin and Hannibal Price. And, like Firmin, he recognized the fundamental «métissage» (mixed race heritage) not only of the New World populations, but of humanity itself. In the context of Price-Mars's appreciation of his and Haiti's African ancestry, he takes the opportunity to comment upon this diverse heritage (Price-Mars 1967: 6).

«Well, our only chance to be ourselves is by not repudiating any part of our ancestral heritage. And, as for this heritage, eight-tenths of it is a gift from Africa. Moreover, on this small planet which is but an infinitesimal point in space, men have intermingled for millennia to the point that there is no longer a single authentic savant, not even in the United States of America, who seriously supports the theory of pure races. And if I accept the scientific position of Sir Harry Johnston there is not a single Negro, as black as he may be, in the center of Africa who does not have some Caucasoid blood in his veins, and perhaps not a single white in the United Kingdom of England, France, Spain, and elsewhere among the most haughty, who has not some drops of Negro or yellow blood in their veins. So, it is true according to the verse of the poet: "All men are man".»

24 I was struck by Price-Mars's last line because it repeats the last words of Anténor Firmin in The Equality of the Human Races, quoting Victor Hugo «All men are man» completing his thought with the «divine instruction» to «love one another» (Firmin 2000: 451).

\section{On Africa and Africans}

The knowledge of the two scholars of Africa and Africans can be contrasted. Firmin was largely ignorant of the contemporary African continent of his day, recalling that much of the African interior had yet to be fully explored and mapped at the time of the writing of De l'égalité des races humaines, in 1885 . The Berlin Congress dividing the continent amongst 
the major European powers had occurred the year before, in 1884. Myth, inferiorized peoples, and tales of monstrosity characterized European views of Africa. Lacking accurate knowledge of the present and adhering to the dictates of science, Firmin declared (2000: 401): «I want to limit myself to generally known fields where serious discussions can be conducted with evidence and verification.» Thus, he turned to Africa's glorious past in support of his anti-racist theory. He devoted much attention to the ancient Nile Valley, recognizing the achievement of Nubia (Ethiopia) as well as the better known Egypt, understanding well ahead of his time the rivalry between the two separate, yet fraternal, civilizations. By contrast, more than four decades later, Price-Mars used Haitian folklore as a key to Haiti's African past and present links. Price-Mars's reference to Africa was to «the Congo, the Sudan, Dahomey», while Firmin conjured the ancient Nile, Egypt, Ethiopia - from «Memphis to Meroë» - in support of Africa's contribution to the civilization of the Black race. Price-Mars rejected the «Dark Continent» characterization, relying upon works of Joseph Deniker, W.E.B. DuBois and Maurice Delafosse. He found the heart of Haitian culture through its folklore and religion in Ainsi parla l'oncle (1928), a classic work of anthropology and ethnology that demythologizes Vodou, establishing its study as a legitimate branch of comparative religion that can be understood only by examining French Catholicism and West African animistic beliefs and practice.

At the "Address Given at Primavera»" eight years earlier in 1922, he discussed peasant life showing «survivals from the land of Africa» - derived from vestiges, survivals of ancient customs, beliefs, mores, through a process of recovery after African civilization sifted through the French sieve. Moreover, he told the story in Creole through the words and feelings of the Haitian masses. Both Price-Mars and Firmin emphasized the importance of Creole as transitional to French in Haitian education, and both saw in the American Tuskegee approach of Negro self-determination through education and economic enterprise an example for Haitian development.

Like Firmin, Price-Mars accepted the strong influence of environment upon African cultural development. As Jacques Antoine noted (1981:140) «the Black man of the US and the Black natives of Africa are no longer his brothers; they have become his very self. This is the transformation that occurs in Ainsi parla l'oncle, also noted in M. Shannon's translation. So Spoke the Uncle (1990: 66-69)». Price-Mars used a shared African heritage to try to fuse a national consciousness, although he understood very well that many Haitian intellectuals critiqued Ainsi... as too African, or, as Haitian anthropologist Rémy Bastien stated, the book idealized the peasant too much. Price-Mars was conscious that he was entering a racially contested ground by evoking the African present in Ainsi..., as Firmin was in his assertion that ancient Egypt is «wholly African» in De l'éga-lité des races humaines.

«Shall we go back together to those times to compare the establishment of a family somewhere in the Congo, in the Sudan, and in Dahomey? Ah! I understand full well the repugnance with which I am confronted in daring to speak of Africa and African things. The subject seems vulgar to you and entirely devoid of interest, am I not right? Beware, my friends, are not such sentiments resting on the grounds of scandalous ignorance? We subsist on ideas [...] in which we glorify the Gauls, our ancestors» (Price-Mars 1990: 204). humaines in 1885 legitimated the study of Africa in its own right, and exerted a major effort to rehabilitate Haitian culture for itself and for the world by valorizing not only 
Haitian intellectuals and folklore but the past and present grandeur of Africa. Price-Mars was less skeptical than Firmin was in his day that contemporary African culture was as great a source of pride in Africa as its glorious past.

\section{On slavery}

Both scholars decried the trade in African humanity for the incalculable losses that the African continent suffered and for the destruction of mind, soul, and spirit that resulted from the centuries of abuse of innocent people. Anténor Firmin was well-acquainted with Frederick Douglass's, Narrative of the Life of an American Slave, published in 1845, forty years before De l'égalité des races humaines, which he quotes at length. Rather than citing the portions of the Narrative... that deal with Douglass's beatings and torture inflicted upon him and the general brutality wrought upon the slaves to which he bears witness, he focuses on his transformative moments of resistance against the slave-breaker Covey (Firmin 2000: 332-333). Firmin sees Douglass as one of America's most illustrious «mulattos» judging him not as «Black» using America's one-drop rule, but by the account of his own birth from his enslaved black mother and from a white father of indeterminate identity, but likely his mother's master. This prior knowledge and sympathy with Douglass makes the encounter between the two men over the Môle of St. Nicolas Douglass as Consul General of the United States in Haiti and Firmin as Minister of Foreign Affairs - all the more interesting and dramatic.

Poster advertising a slave's auction ca 1763

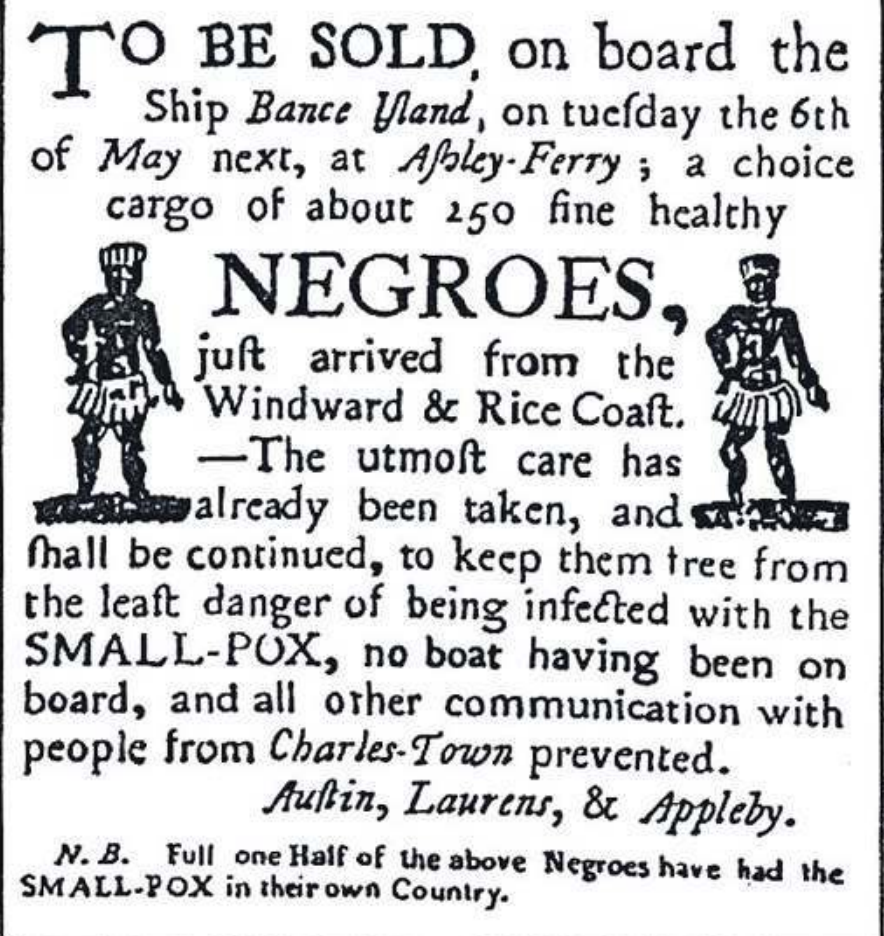

Firmin wrote vigorously against slavery as the institution related to the doctrine of the inequality of races. He contrasted the more «timid» pro-slavery ideas of the nonslaveholding nations of Europe with the unapologetic defense of slavery in the United 
States, and he noted that pro-slavery sentiments were to be found among anthropologists who counted themselves as monogenists and polygenists alike.

«The anti-philosophical and anti-scientific doctrine of the inequality of the races rests on nothing more than the notion of man's exploitation by man. Only the American school has shown any honesty and consistency in its support of the doctrine, for its tenants have never hidden the interest that they have had in its promotion. While accepting the idea of the plurality of species and their comparative inequality, the European scientists will protest against slavery in magnificent tirades. Broca, for example, who does not hesitate to say what he thinks of the Ethiopian Black, indignantly raises his voice against slavery» (Firmin 2000: 140).

Firmin's empathy with the condition of enslavement is deep and profound, whether discussing racial myths of docility, indolence, or feigned ignorance in the face of the brutal dominance of slave-master over slave. He extolled especially the accomplishments of Haiti's métis (mixed race persons) triumphing over their suffering as «mulattos». His focus on the fecundity and biological vigor of the New World's racially mixed persons was meant to challenge the «scientific» view of many anthropologists and other scientists on the infertility of the offspring of Black and White. More amused by this assertion than agitated, he pointed to the vigorous, hybrid populations of New World societies, including the growing populations of Haiti and the Dominican Republic as examples that racially mixed people reproduce as well as any other. The fact was that few Black voices on the subject of race were to be heard, which was one of the stated reasons for Firmin's book. Responding to the postulate made by Quatrefages that Black people sweat less than White people, he speaks with authority on the subject:

«I am Black and nothing distinguishes me anatomically from the purest Sudanese. However, I transpire abundantly enough to have some idea of the facts. My congeners are not beyond the laws of nature. I shall not bother to discuss the issue of the putative sui generis odor that is supposedly a particular characteristic of the Negro race. The idea is more comical than scientific» (Firmin 2000: 61-63).

For Price-Mars slavery was the institution that brought African culture to the New World societies and provided the conditions under which languages and cultural traits were transmitted, destroyed, modified, and created anew. And for Firmin, Price-Mars, and virtually all intellectuals, as well as for the Haitian masses, it was slavery that provided the essential context for the glorious Haitian Revolution that had been the defining event for Haiti and for the emancipation and vindication of the Negro.

"Yes, for four hundred years the white race without pity or mercy, has kindled internal warfare in Africa, turning Negro against Negro, pursuing him like game without truce or mercy in order to satisfy its unspeakable traffic in human flesh, destroying all indigenous civilization and culture. For two centuries moreover it urged its boats loaded with human cattle toward the shores of this island already bloodied by the extermination of the Indian, and during two centuries of outrageous promiscuity, of corruption, and of degeneration it sullied the age-old chastity of the black woman imposing upon her the brutal role of concubinage. And so the status of the Negro family has been denigrated, destroyed, annihilated by the most wretched abomination that has ever maculated the face of the earth, so truly that shortly after 1804 our fore fathers committed themselves to the most formidable experiment that has been attempted among men» (Price-Mars 1990: 217).

Firmin says all of this about slavery and its effects upon the Negro mind, body, and soul; and more as he looks to a future when the educated «Ethiopian» will read into the past of 
human history and pass his own judgment upon what has been done to him and what he has done to others.

\begin{abstract}
«Instead of harboring hatred in his heart, he will generously spread the inexhaustible love of which he is naturally endowed, so much so that those who do not know the rich and varied qualities of his temperament will read into it a feminine trait even as they behold him at his most masculine behavior. Facing the other races, he will remember his days of humiliation under the yoke of slavery, when he was forced to pay with his sweat for the luxurious way of life of the Sybaritic colonizer. As he reviews the past he will remember that there was a time when the savage Tamahov and the humble Amov, the children of Seth and Japheth were themselves under the harsh rule of his Black ancestors. The gigantic monuments which are the glory of Egypt had been built with the labor of Whites from the East and the West. Humanity is one in time as it is in space; the injustices of past centuries echo those of the present centuries» (Firmin 2000: 447).
\end{abstract}

This passage reveals the essential humanism as well as scientific positivism that underlies Firmin's The Equality of the Human Races and why his anthropological work inspired not only Jean Price-Mars but subsequent generations of anthropologists who are now able to read his long obscured work.

\title{
Firmin's ties to american anthropology
}

We can now draw a line from Anténor Firmin to Jean Price-Mars; from Jean Price-Mars to Melville Herskovits; from Melville Hersko-vits to Franz Boas; and thus from Anténor Firmin to the mainstream of American anthropology. There may well be comparable connections between Haitian ethnology and French anthropology, however these have yet to be retraced from the submerged history of science and intellectual life among the enslaved and colonized peoples and nations.

The admiration of Firmin by Jean Price-Mars is clear. That he is the most obvious 20th century intellectual descendant of Firmin's anthropology and the founder of ethnological studies in Haiti is also clear. However, Firmin's contribution to American anthropology came indirectly through his profound influence upon Jean Price-Mars, the dean of 20th century Haitian ethnology who was closely associated with Melville Herskovits, a student of Franz Boas and founder of African Studies in America and of Afro-American anthropology.

Correspondence between Melville Herskovits and Jean Price-Mars, from 1928 to 1955, reveals a warm and affectionate professional relationship between the elder scholar Price-Mars and the young Herskovits ${ }^{10}$. This began as the American anthropologist developed an interest in Caribbean and South American Negroes, after his original studies of the American Negro, and as he later planned a period of research in Haiti. Price-Mars responded generously to Herskovits's requests, replied to his questions about Haitian ethnology, and even encouraged the young American scholar. Eventually, Herskovits did conduct several months of fieldwork in Haiti in 1934, with Price-Mars arranging for the visit and hosting Herskovits and his wife, selecting the field location of Mirebalais, assisting with housing and introductions, and providing a senior ethnologist's advice, perspective, and scholarly resources. This resulted in the publication of Melville Herskovits's classic Life in a Haitian Valley (1937) in which he credits Price-Mars and his colleague J. C. Dorsainvil with critical assistance: 
«Aid and inspiration were derived from many friendly conversations with two outstanding students of Haitian folk-life, Dr Price-Mars and Dr J. C. Dorsainvil. My indebtedness to the works they have published on the subject is shown by the references to their publications given at the end of this volume, for their researches must be accepted as basic by any serious investigator of Haitian customs. Their cordial advice to a fellow-student constitutes one of the most pleasant memories of this fieldwork...» (ibid.: $\mathrm{x}$ )

This published acknowledgment of Price-Mars is corroborated in his private correspondence:

September 23, 1936, Melville Herskovits to Jean Price-Mars

«...I was able to finish my book on Mirebalais - you will see that I am restricting myself to life in the valley where I studied, and not attempting to write about the whole of Haiti - and at the same time get a much needed rest in the countryside where we were living. The book should appear during the winter and, needless to say, I will see that a copy is sent to you. You will find that I have made good use of your work which I found of great value; I shall look forward with interest to your comments on my report».

\section{September 26, 1934 Melville Herskovits to Jean Price-Mars}

«... I do want to write and tell you how much I enjoyed the time I spent with you while I was in Haiti and also to convey to you my appreciation of the material aid you gave me in making possible our research in Mirebalais. Just as it would not have been possible without your aid to have got my films through the customs, so our work would have been less productive without the help which General Cantave gave me as a result of my having been introduced to him by means of the card from you which I carried (best wishes on your senatorial and presidential campaigns) $»^{11}$.

Price-Mars continued his interest in Herskovits's work, later suggesting that a translation of Life in a Haitian Valley be undertaken, and in return, in 1933, Melville Herskovits offered to nominate Jean Price-Mars for membership in the American Anthropological Association. 


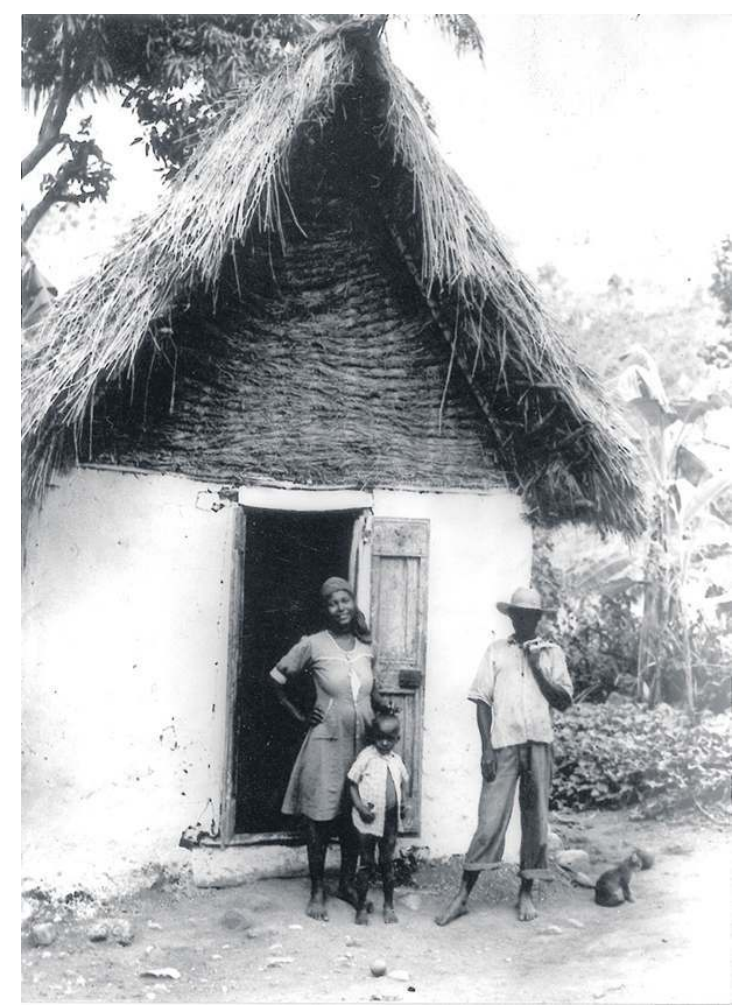

() musée du quai Branly, droits réservés

In 1920 Price-Mars held an historic conference on «Haitian Folklore» at the Cercle Portau-Princien at which he introduced the serious study of Vodou gaining respect of Haitian and French intellectuals. Price-Mars's opening line in his classic work Ainsi parla l'oncle (1928) - «What is Folk-Lore?» - is an eminently anthropological question to which Boas and many of his famous students often turned. To this question he responded, «Folk-lore is comprised of the legends, customs, observances which form the oral traditions of a people. And for the Haitian people, they are the fundamental beliefs upon which have been grafted or superimposed other more recently acquired beliefs» (ibid.: 13). Uncle Bouqui is the prototypical Haitian story teller, "Cric?» asks the story teller, «Crac!», replies the audience (ibid.: 17). This became the title of a US national book award for Krik? Krak!, stories written by the contemporary Haitian novelist, Edwige Dandicat (1991).

Price-Mars received other American students of anthropology besides Herskovits, including Katherine Dunham ${ }^{12}$ in 1935, whom he helped with her work on Afro-Caribbean dance - a new subject of research in anthropology -, and also George E. Simpson (1990). Jean Price-Mars wrote a number of anthropological and ethnological books ${ }^{13}$. He enjoyed a long and vital career as a scholar and politician. In addition to his being a founder of the Société d'histoire et de géographie d'Haïti, he also ran for President of Haiti in 1940, and in the 1950s was appointed Head of the Haitian Delegation to the United Nations. During his long career he achieved some of the international recognition that Firmin's relatively briefer life did not permit. Louis Mars, Jean Price-Mars's son became a recognized scholar in his own right as Director of the Institute of Ethnology in the 1950s.

As we assess the contributions of great figures in American anthropology, such as Franz Boas and Melville Herskovits, a broader net should be cast to ensure that the scholars 
from outside of North America whom they influenced and who influenced them, are also considered. Two Haitian giants, Anténor Firmin and Jean Price-Mars, should gain admittance to the mainstream of world anthropology and be assessed not only in their own right, but for their signal contributions to ethnology and anthropology. So far, the factor of race has been the main hindrance to their recognition.

Firmin died in 1911 at age 61, in exile in St. Thomas, while Price-Mars lived out his nine decades mostly in Haiti where members of his family still reside. Magdaline Shannon explains in her translation of Ainsi... that America only became interested in Price-Mars in the late 1970s, while the academic world outside of Haiti is only now being introduced (or in the case of France, re-introduced) to Anténor Firmin. As Leon Damas noted, when Price-Mars was honored by the Académie française, «not only as a writer but also as a man, especially for his courage, his mettle, and for that intellectual honesty which he never ceased to display in the interest of the triumph of ideas not long since regarded as subversive» ${ }^{14}$. Firmin's ideas were perhaps also considered to be subversive in the late 19th century making a powerful case for the equality of races. This also delayed the development of an early critical and progressive vision of anthropology that challenged the race concept.

\section{BIBLIOGRAPHY}

ADAMS, William Y.

1998 The Philosophical Roots of Anthropology. Stanford, CA, Center for the Study of Language and Information Publications.

ANTOINE, Jacques C.

1981 Jean Price-Mars and Haiti. Washington, DC, Three Continents Press.

BOAS, Franz

1911 The Mind of Primitive Man. New York, Macmillan.

1940 Race, Language and Culture. New York, The Free Press.

COUTHARD, G. R.

1962 Race and Colour in Caribbean Literature. London-New York, Oxford University Press.

DANDICAT, Edwige

1991 Krik? Krak! New York, Vintage Books

DOUGLASS, Frederick

1845 Narrative of the Life of an American Slave. Boston, Anti-Slavery Office.

FIRMIN, Anténor

1885 De l'égalité des races humaines. Paris, Cotillon. 
2000 The Equality of the Human Races. Transl. by Charles Asselin, introd. by Carolyn Fluehr-Lobban. New York, Garland Press.

FLUEHR-LOBBAN, Carolyn

2000 «Anténor Firmin: Haitian Pioneer of Anthropology», American Anthropologist, 102 (3):

449-466.

FOUCHARD, Jean

1990 «Introduction», in Jean Price-Mars, So Spoke the Uncle, transl. by Magdaline Shannon. Washington, DC, Three Continents Press: V-VI.

GOBINEAU, Joseph Arthur de

1853-1855 Essai sur l'inégalité des races humaines. Paris, 4 vol.

HARRIS, Marvin

1968 The Rise of Anthropological Theory. New York, Thomas Crowell.

HERSKOVITS, Melville

1937 Life in a Haitian Valley. New York, Alfred A. Knopf.

LE BON, Gustave

1894 Les Lois psychologiques de l'évolution des peuples. Paris, Alcan (Engl. transl. The Psychology of Peoples. London, 1898).

LESPINASSE, Beauvais

1882 Histoire des affranchis de Saint-Domingue. Paris, Kugelmann.

MARTIN, Richard

2001 Frederick Douglas, Anténor Firmin and the Môle of St. Nicolas. Providence, Rhode Island College, MA thesis.

MORGAN, Lewis Henry

1877 Ancient Society. New York, H. Holt \& Co.

PARSONS, Talcott

1949 The Structure of Social Action. New York, The Free Press (1st ed. 1937).

PRICE, Hannibal

1900 De la réhabilitation de la race noire par la République d'Haïti. Port-au-Prince, J. Verrollot.

PRICE-MARS, Jean

1928 Ainsi parle l'oncle... Essai d'ethnographie. Compiègne, Imprimerie de Compiègne.

1929 Une étape de l'évolution haïtienne. Port-au-Prince, Imp. «La Presse».

1939 Formation ethnique, folklore et culture du peuple haïtien. Port-au-Prince, V. Valcin, Imp.

1967 Lettre ouverte au Dr René Piquion : le préjugé de couleur est-il la question sociale? Port-au-Prince, Les Éditions des Antilles.

1978 Anténor Firmin. [Port-au-Prince], Imp. Séminaire adventiste.

1990 So Spoke the Uncle. Transl. and introd. by Magdaline Shannon, Washington, DC, Three Continents Press. 
SHANNON, Magdaline W.

1996 Jean Price-Mars, the Haitian Elite and the American Occupation, 1915-35. New York, St Martin's

Press.

SIMPSON, George A.

1990 «Preface», in Jean Price-Mars, So Spoke the Uncle, transl. by Magdaline Shannon.

Whashington, DC, Three Continents Press: VII-VIII.

TOPINARD, Paul

1885 Éléments d'anthropologie générale. Paris, A. Delahaye \& É. Lecrosnier.

TYLOR, Edward Burnett

1881 Anthropology: An Introduction to the Study of Man and Civilization. London, Macmillan.

\section{NOTES}

1. In 1988, as I was lecturing about Gobineau's Essai sur l'inégalité des races, a Haitian student, Jacques R. Georges, extolled De L'égalité des races humaines. This was how I learned about Firmin.

2. The other Haitian members wereJ.B. Dehoux, founder of the Medical School in Haiti, and Louis-Joseph Janvier who remained in Paris for twenty-eight years and wrote a number of works including an essay with a similar title, L'Égalité des races, in 1884.

3. Ghislaine Geloin, personal communication, Providence, 2001. I express my gratitude to Ghislaine Geloin Professor of French at Rhode Island College for discovering these facts at the Archives de la Societé d'Anthropologie de Paris in 2000. Further discussion of her findings can be found in her paper on the reception of Firmin's book in France that was presented at the conference, «Anténor Firmin: Pioneer of Anthropology, Pan-Africanism and Post-colonial Studies», held at Rhode Island College in June 2001, and in her introduction to a new French edition of De l'égalité des races humaines..., published in 2004 by L'Harmattan in Paris .

4. Lyle Shannon has assumed the considerable mantle of responsibility for maintaining contact with scholars interested in the lifelong work in Haitian studies of his wife Magdaline Shannon who is no longer able to do so. In addition to her translation of Ainsi parla l'Oncle, she is the author of a book on Jean Price-Mars (1996).

5. Those chapters are: «Egypt and Civilization»; «Intellectual Evolution of the Black Race in Haiti»; «Evolutionary Pace of the Black Race» and «The Role of the Black Race in the History of Civilization» .

6. Proposed Plan for the Encyclopaedia Africana: For the Attention of the members of the Editorial Board and the National Cooperating Committees of the Secretariat. Accra, Secretariat for an Encyclopaedia Africana, 1964.

7. Lyle Shannon, personal communication, October 20th, 2000.

8. The encounter between American Ambassador, Frederick Douglass, and Haitian Minister of Foreign Affairs, Anténor Firmin, as well as the diplomatic affair between the two countries when the United States attempted to acquire the Môle of St. Nicolas as a naval base has been studied by Richard Martin (2001) incorporating both Haitian as well as American perspectives.

9. Reprinted in So Spoke the Uncle, 1990.

10. I am grateful to Kevin Yelvington for sending me a copy of this entire correspondence as a resource for the preparation of this article. As a graduate of Northwestern University's Program of African Studies which Herskovits founded, I feel a personal connection to these Caribbean and American scholars, Anténor Firmin, Jean Price-Mars and Melville Herskovits. 
11. Correspondence between Melville Herskovits and Jean Price-Mars (Melville J. Herskovits Library of African Studies, Melville J. Herskovits Papers, Africana Manuscripts 6, Box 19, Folder 1, Northwestern University, Evanton, IL).

12. Letter to Melville Herskovits, 29 June 1935 in Melville J. Herskovits Library of African Studies...

13. See bibliography

14. Price-Mars (1990: XXVII).

\section{ABSTRACTS}

Carolyn Fluehr-Lobban, Anténor Firmin and Haiti's contribution to anthropology (1850-1911) Anténor Firmin was an anthropologist who pioneered a critical study of race and physical anthropology and developed in his major work, De L'égalité des races humaines..., a vision of anthropology as an integrated study of humanity. The publication date of 1885 of De L'égalité des races humaines marks it as a pioneering text in anthropology and it is perhaps the first major work of anthropology written by a person of African descent. Although Firmin's tome was lost to Francophone anthropology, it was recognized not only in Haiti but also among Pan-Africanist scholars as an early work of négritude. Anténor Firmin also had a seminal impact on Jean PriceMars, the 20th century founder of Haitian ethnology, and these ties extend further to the American founder of African and Afro-American anthropology, Melville Herskovits.

Anténor Firmin fut l'un des premiers anthropologues qui porta un jugement critique sur la notion de «race», aussi l'anthropologie physique forme-t-elle la partie principale de son œuvre. De l'égalité des races humaines, dont la publication date de 1885 , constitue un texte pionnier en la matière. En outre, il s'agit peut-être là de la première œuvre majeure d'anthropologie rédigée par un chercheur d'ascendance africaine. Même si le texte d'Anténor Firmin resta longtemps lettre morte pour l'anthropologie francophone, il fut reconnu non seulement en Haïti, mais aussi parmi les scientifiques panafricains comme une œuvre «annonçant» la négritude. Anténor Firmin eut non seulement une influence profonde sur Jean Price-Mars, le créateur, au xxe siècle, de l'ethnologie haïtienne, mais ces liens s'étendirent plus loin, jusqu'à Melville Herskovits, fondateur de l'anthropologie africaniste et afro-américaniste.

\section{INDEX}

Mots-clés: anthropologie physique, anthropologue noir, ethnologie haïtienne, Jean Price-Mars, négritude, panafricanisme

Keywords: black anthropologist, Haitian ethnology, Jean Price-Mars, negritude, Pan-Africanism, physical anthropology

\section{AUTHOR}

\section{CAROLYN FLUEHR-LOBBAN}

Rhode Island College Providence, Rhode Island cfluehr@ric.edu 